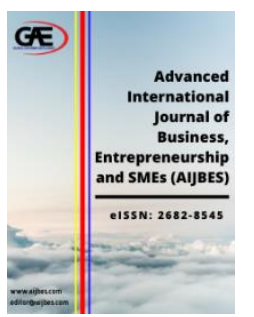

\author{
ADVANCED INTERNATIONAL JOURNAL OF \\ BUSINESS, ENTREPRENEURSHIP AND SMES \\ (AIJBES) \\ www.aijbes.com
}

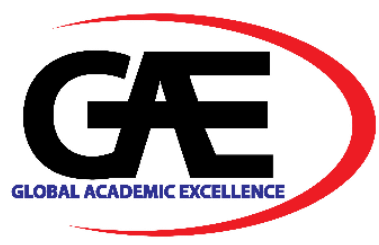

\title{
RELATIONAL STUDY BETWEEN MACROECONOMIC VARIABLES AND GOLD PRICE: LATEST MALAYSIAN EVIDENCE
}

\author{
Mohamad Azwan Md Isa ${ }^{*}$, Ruziah A Latif ${ }^{2}$, Ferri Nasrul ${ }^{3}$, Zaibedah Zaharum ${ }^{4}$, Mohd Khairul Ariff \\ $\mathrm{Noh}^{5}$
}

1 Faculty of Business and Management, Universiti Teknologi MARA, Johor, Malaysia

Email: moham821@uitm.edu.my

2 Faculty of Business and Management, Universiti Teknologi MARA, Johor, Malaysia

Email: ruzia418@uitm.edu.my

3 Faculty of Business and Management, Universiti Teknologi MARA, Johor, Malaysia

Email: ferri@uitm.edu.my

4 Faculty of Business and Management, Universiti Teknologi MARA, Johor, Malaysia

Email: zaibe101@uitm.edu.my

5 Faculty of Business and Management, Universiti Teknologi MARA, Johor, Malaysia

Email: ariff890@uitm.edu.my

Corresponding Author

Article Info:

\section{Article history:}

Received date: 15.10 .2020

Revised date: 20.10 .2020

Accepted date: 05.11.2020

Published date: 01.12.2020

\section{To cite this document:}

Isa, M. A. M., Latif, R. A., Nasrul, F., Zaharum, Z., \& Noh, M. K. A. (2020). Relational Study between Macroeconomic Variables and Gold Price: Latest Malaysian Evidence. Advanced International Journal of Business, Entrepreneurship and SMEs, 2 (6), 01-09.

DOI: $10.35631 / \mathrm{AIJBES} .26001$.

\section{Abstract:}

Gold is one of the world-leading commodities, which is sought after as jewellery as well as an investment. Despite gold advantage as a reliable store of value, its price has been as fluctuating as other commodities or assets such as crude oil and stock. Therefore, investors should be aware that gold is not totally resistant to market turmoil and economic crisis. Gold could be as vulnerable as other traditional investment vehicles. Hence, this paper focuses on investigating the macroeconomic variables affecting gold prices in Malaysia using monthly data from 2014 to 2018 . This study uses Pearson Correlation and Multiple Linear Regression tests to determine significant relationships and effects between the independent variables, namely interest rates, inflation rates, crude oil price, and exchange rates with the dependent variable, namely gold price. The findings show that the interest rate has a significant negative effect on gold price while inflation rate, crude oil price, and exchange rate have a significant positive effect on gold price in Malaysia, respectively. The results suggest valuable information and insight to policymakers, researchers, and investors in decision making. 
Keywords:

Gold Price, Interest Rate, Inflation Rate, Crude Oil Price, Exchange Rate, Malaysia

\section{Introduction}

Gold is very precious and one of the world leading commodities as the value of gold remains stable or rises regardless of the periods of economic, financial or political crises. In fact, gold has its own standard value that is not being easily affected by any crisis. According to Sukri, Mohd Zain, and Zainal Abidin (2015), gold is a good investment, which is neither short-term nor long-term and a great asset that has higher liquidity. However, over the years, the cost of gold has significantly increased due to high demand. It is very important to those who plan to buy gold to understand the nature of investing in gold before making any decision of taking gold as an investment. Thus, it will give the investors opportunity to benefit and profit from gold as an alternative asset. Even though gold price can be measured or forecasted, but its value is still affected by the economic crisis and the impact of the crisis on the gold price cannot be controlled.

The demand on gold has increased year by year particularly in the jewellery or business sector because of its importance and benefit as a store of value (Toraman, Basarir \& Bayramoglu, 2011). Among all precious metals, gold might be the most popular choice for investment. It has stood the test of time and performed well during economic turmoil such as market crash, currency failure, high inflation, war and so on. Gold is regarded as a good insurance against inflation as well as when there is a fall in value of other assets' price such as stocks, bonds and foreign currencies. The benefit of gold as an inflation hedge simply implies that when general prices of goods are on the rise, gold price will also be on the rise so that the gold can be liquidated in order to finance general spending activity. In other words, gold plays important role in investment portfolio diversification.

Over the last decades, the demands and price of gold have been very high compared to other standard commodities due to the exclusiveness of the gold itself. Gold investment has been practiced by investors a long time ago. During the early stage of the economy, the price of gold was not determined by the supply and demand of gold but instead had been determined by its special features of exclusiveness. In the past, gold was used as money or currency and even today, it has the power of money and people seem to be using this as an option despite real estate has lately displaced the position of gold as the best investment option even though it has very low liquidity. Gold is an asset that no-one else's liability unlike other investment which is dependent on other factors of market demands.

Nevertheless, in this new era, the value of gold is closely related to the economy all over the world, where the gold price may vary or change by day or even by hours. This condition will give bad effect to investors. Thus, it is essential for investors to have proper way or guidance to encounter this issue so that they can plan on this gold investment efficiently. Unfortunately, nowadays, the paper notes and coins that we call money have no backing in gold. Great Britain and other major European countries came off the gold standard in the 1920s and 30's. Switzerland stopped backing each franc that it issued with gold in 1936.Three decades later, the United States finally cut the world supply of money free from gold when it stopped swapping Dollars for bullion at the Federal Reserve in 1971. Over the nine years that followed, 
namely in 1980s, the price of gold in Dollars rises more than 23 times over. The gold price sank for the next 20 years, falling lower as the world monetary system stabilized.

Therefore, this study aims to investigate the correlation and relational impact between gold price and macroeconomic variables based on the Malaysian evidence. It is hoped that the findings of this study will shed light on the economic factors that influence the gold price, which will be useful insight to the investors, policy makers and researchers. The remainder of this paper is arranged as follows; 2) literature review; 3) data and methodology; 4) results and discussion; and 5) conclusion and recommendation.

\section{Literature Review}

Many studies have been conducted to determine the factors that influence the price of gold. According to Sukri et al., (2015), gold is now an attractive investment option. This is due to the durability of the gold itself, and other attributes like homogeneous and fungible. Ibrahim et al., (2014) found that investors took advantage of gold price differences by buying at lower rates and selling at higher rates. This is happening among the investors community in Malaysia. There is a tendency among Malaysians to buy gold as a form of savings scheme because of its easily convertible nature to money considered as a form of liquid asset. It is also a symbol of one's personal wealth. Another study shows that gold prices are also influenced by inflation rate, exchange rate and real interest rate (Zakaria, Abdul Shukur, Affandi, \& Wan Mahmood, 2015).

Tram (2014) found that there is a negative one-way relationship between gold prices and interest rates. It is concluded that when interest rates fall, and gold prices rise and vice versa. It has also been evidenced by a study of Toraman et al., (2011), where they the similar results. The study further indicated that interest rates will lose its strong impact on gold prices as more inflation and physical demand emerge. Zakaria et al., (2015) showed that interest rates and gold prices are negatively related. The study concluded that downward and upward demand from investors for gold will also lead to its price changes. The finding is then supported by Laily et al., (2017). Beckmann et al., (2013) stated that when inflation rate is higher than nominal interest rate, creditors will lose their money. As a result, they will turn to gold as a new investment because of its value-based nature even though it does not provide any current benefits or income. Jaraskunlanat et al., (2016) proved contradictory result, where they did not find any significant impact by interest rates on gold prices in Thailand despite of positive relationship between the two.

Purchasing power in the economy measured by the inflation rate is positively related to the gold price. San et al., (2012) stated that when inflation occurs, gold prices will generally rise. This shows that gold is the best asset for investment and also as an inflation hedge. This finding is supported by Sindhu (2013), who noted that this phenomenon caused gold prices to rise due to high demand from investors, who hold gold as an investment vehicle. A study in Malaysia by Zakaria et al., (2015) suggested that gold is the best asset as a hedge against rising prices in a sustained economy. Worthington and Pahlavani (2007) indicated the strong linkage between gold prices and inflation. They added that returns on gold were not able to hedge against inflation during the low-price adjustment regime in the US and Japan compared to the period during the high momentum regime. Nevertheless, there are few studies concluded that inflation and gold prices are negatively related such as Qian et al., (2019), Ibrahim et al., (2014) and Toraman et al., (2011). Tully and Lucey (2007), and Blose (2010) stated that there is no significant positive relationship between the Consumer Price Index and gold prices. 
Volume 2 Issue 6 (December 2020) PP. 01-09 DOI 10.35631/AIJBES.26001

Sindhu (2013) showed that inflation due to the increase in crude oil price will eventually lead to investment in gold. This is also driven by the falling buying power because of inflation, which prompted investors to shift their investment to gold due to its stable value. Gold and crude oil prices were found to be positively correlated based on a study by Shafiee and Topal (2010). The study claimed that when oil prices rose due to the oil crisis as a result of declining crude oil production during the wars between Iran and Iraq, gold prices rose as well. Laily et al., (2017) indicated a significant impact between crude oil price and gold price. They proved that a USD1 rise in crude oil price results in USD 10,265 rise in gold prices. However, there are few studies that found negative relationships and insignificant impact of crude oil price on gold price like studies by Tram (2014) and Qian et al., (2019).

According to Ling (2011), most countries now adopt floating exchange rates for their respective currencies. This has been the case since the end of the Bretton Woods System and Gold Standard financial mechanisms. However, gold prices are still affected by the exchange rate of the US dollar as the majority of gold in the world is priced against the US Dollar. Ibrahim et al., (2014) and Zakaria et al., (2015) found negative relationship between exchange rate and gold price. They added that this can provide a hedge on the value of wealth and purchasing power to those who have gold reserves. Tsen (2014) and Laily et al., (2017) also concluded negative relationship between the exchange rate and gold price even though there is no evidence of significant impact between the two. However, there are studies that prove otherwise. Akar (2011), and Zagaglia and Marzo (2013) found a positive relationship between gold and foreign exchange. Tram (2014) showed mixed results, where there is a positive relationship between exchange rate and gold price based on a week-long movement of change. But, this had changed to a negative relationship for five-week long before returning to positive.

\section{Data and Methodology}

This study employs monthly data for gold price and Malaysia macroeconomic variables for the period from 2014 to 2018, thus the sample consists of 60 observations for each variable. The data is collected from the database of Malaysian Statistics Department and Index Mundi website. Time series data analysis is applied to analyse the effect of macroeconomic variables on gold price. The following equation is estimated to find such effect:

$$
G P=\beta 0+\beta_{1} I R+\beta_{2} I N F+\beta_{3} C O P+\beta_{4} E X C+\varepsilon
$$

Where; $G P$ represents gold price, $I N F$ is the inflation rate, $C O P$ represents the crude oil price, $E X C$ is the exchange rate, $I R$ is the interest rates and finally $\beta 0$ and $\varepsilon$ represent the intercept and the random error term, respectively. Table 1 shows the description of each variable.

Table 1: Description of Data

\begin{tabular}{lll}
\hline Name of variables & Symbol used & Proxy used \\
\hline Gold Price & GP & MYR per troy ounce \\
\hline Inflation Rate & INF & Consumer price index (CPI) \\
\hline Crude Oil Price & COP & MYR per barrel \\
\hline Exchange Rate & EXC & MYR to USD \\
\hline Interest Rate & IR & Base lending rate (BLR) \\
\hline
\end{tabular}


Volume 2 Issue 6 (December 2020) PP. 01-09 DOI 10.35631/AIJBES.26001

Based on the literatures reviewed, the hypotheses for this study have been developed as follows:

H1: There is a positive significant effect of inflation rate on gold price.

H2: There is a positive significant effect of crude oil price on gold price.

H3: There is a negative significant effect of exchange rate on gold price.

H4: There is a negative significant effect of interest rate on gold price.

The collected data was analysed using EViews 10 statistical software. We begin analyse the data using the unit root and multi-collinearity tests. Next, Pearson's correlation analysis was performed to study the correlation among the variables. Finally, multiple linear regression analysis was conducted to find the significance and effect of the selected macroeconomic variables on the gold price.

\section{Results and Discussion of Findings}

\section{Unit Root Test}

The test used is based on the Augmented Dickey-Fuller (ADF). The data was standardized and transformed into percentage change.

Table 2: ADF Unit Root Test Results

\begin{tabular}{|c|c|c|c|c|}
\hline \multirow{2}{*}{ Variable } & \multicolumn{2}{|c|}{ Level } & \multicolumn{2}{c|}{$\mathbf{1}^{\text {st }}$ Difference } \\
\cline { 2 - 5 } & No Trend & Trend & No Trend & Trend \\
\hline GP & -1.515 & -1.628 & -7.204 & -6.222 \\
\hline & 0.519 & 0.769 & 0.000 & 0.000 \\
\hline IR & -3.921 & -3.948 & -9.053 & -8.993 \\
\hline & 0.003 & 0.016 & 0.000 & 0.000 \\
\hline INF & -1.255 & -2.377 & -6.729 & -6.751 \\
\hline & 0.645 & 0.388 & 0.000 & 0.000 \\
\hline COP & -2.327 & -2.158 & -4.897 & -4.940 \\
\hline & 0.167 & 0.503 & 0.000 & 0.001 \\
\hline EXC & -1.487 & -1.333 & -6.890 & -6.930 \\
\hline & 0.533 & 0.870 & 0.000 & 0.000 \\
\hline
\end{tabular}

Table 2 shows the results from the unit root test for all variables of this study, namely gold price (GP), interest rate (IR), inflation (INF), crude oil price (COP) and exchange rate (EXC). Based on the results, the data for the gold price is found to have unit root problem or not stationary at level, where the p-values are larger than 5\% significance level. However, when we converted to the $1^{\text {st }}$ difference, then only the data of gold price has become stationary. The data for interest rate shows that it is stationary at the $1^{\text {st }}$ difference. It is supported by the result of the p-value for the interest rate that is below the significance level at $5 \%$ in the $1^{\text {st }}$ difference for both trend and no trend. Besides, inflation rate is also found to be stationary based on the significant $\mathrm{p}$-values at the $1^{\text {st }}$ difference for both no trend and trend. Likewise, the ADF results for the other two variables, crude oil price and exchange rate are also stationary at the $1^{\text {st }}$ difference for no trend and trend. In a nutshell, all the variables are stationary at the same order, namely at $1^{\text {st }}$ difference. 


\section{Multi-Collinearity Test}

The centered VIF was analyzed to identify the existence of multi-collinearity in the variables. According to the results in the table above, the centered VIF value for Interest Rate is 1.413, inflation rate is 3.381 , crude oil price is 3.638 and exchange rate is 7.441 . The benchmark value for multi-collinearity is 10 and close to 1 . The results show that all the independent variables centered VIF are less than 10 and close to 1 . This means that the data is good and indicates that none of the independent variable has serious collinearity problem.

Table 3: Results of Multi-Collinearity Test

\begin{tabular}{|l|c|c|}
\hline Variable & Coefficient Variance & Centered VIF \\
\hline ZX1 & 26623.730 & 1.413 \\
\hline ZX2 & 234.272 & 3.381 \\
\hline ZX3 & 1.262 & 3.638 \\
\hline ZX4 & 28850.500 & 7.441 \\
\hline C & 2129477.000 & N/A \\
\hline
\end{tabular}

$\mathrm{ZY}=\mathrm{GP} ; \mathrm{ZX} 1=\mathrm{IR} ; \mathrm{ZX} 2=\mathrm{INF} ; \mathrm{ZX} 3=\mathrm{COP} ; \mathrm{ZX} 4=\mathrm{EXC}$

\section{Pearson Correlation Test}

Table 4: Results of Correlation Test

\begin{tabular}{|l|c|c|c|c|c|}
\hline Variable & ZY & ZX1 & ZX2 & ZX3 & ZX4 \\
\hline ZY & 1.000 & & & & \\
\hline $\mathbf{Z X 1}$ & -0.107 & 1.000 & & & \\
& 0.414 & & & & \\
\hline $\mathbf{Z X 2}$ & 0.856 & 0.094 & 1.000 & & \\
& $0.000^{*}$ & 0.472 & & & \\
\hline $\mathbf{Z X 3}$ & -0.562 & 0.202 & -0.431 & 1.000 & \\
& $0.000^{*}$ & 0.121 & $0.000^{*}$ & & \\
\hline $\mathbf{Z X 4}$ & 0.843 & 0.146 & 0.791 & -0.744 & 1.000 \\
& $0.000^{*}$ & 0.264 & $0.000^{*}$ & $0.000^{*}$ & \\
\hline
\end{tabular}

Table 4 shows the results of correlations of each pair of dependent variables with the respective independent variable and among the independent variables as well. The gold price is found to have strong or high positive correlation with the inflation and exchange rates; respectively with the correlation coefficient $(r)$ values are more than 0.80 . This shows that when the inflation and exchange rate rise, it will affect the gold price to rise as well and vice versa. Meanwhile, the interest rate and crude oil price have shown negative correlation with the gold price, where interest rate indicate weak correlation and the crude oil price medium correlation at -0.56 . This indicates that when interest rate and crude oil price increase, it will result in a decrease in gold price. In the term of significance level, the three independent variables, namely inflation rate, crude oil price and exchange rate are found to be significant variables towards the gold price, whereas interest rate is not. Among the independent variables, it is found that exchange rate has quite high correlation with crude oil price and inflation rate at $r$ values more than 0.70 whilst it has low correlation with interest rate. 
Multiple Linear Regression Test

Table 5: Results of Multiple Regressions

\begin{tabular}{|l|c|c|c|c|}
\hline Variable & Coefficient & SE & t-Stats. & Prob. \\
\hline ZX1 & -823.288 & 163.168 & -5.046 & $0.000^{*}$ \\
\hline ZX2 & 68.114 & 15.306 & 4.450 & $0.000^{*}$ \\
\hline ZX3 & 2.519 & 1.123 & 2.242 & $0.030^{* *}$ \\
\hline ZX4 & 922.284 & 169.854 & 5.430 & $0.000^{*}$ \\
\hline C & -3632.396 & 1459.273 & -2.489 & $0.016^{* *}$ \\
\hline R-squared & \multicolumn{5}{|c|}{0.868} \\
\hline Adj. R-squared & \multicolumn{5}{|c|}{0.859} \\
\hline Prob. (F-stats) & \multicolumn{5}{|c|}{0.000} \\
\hline Durbin-Watson stat. & \multicolumn{5}{|c|}{0.850} \\
\hline
\end{tabular}

* significant at $1 \%$ level

** significant at $5 \%$ level

Based on the regression results, all the four independent variables selected, namely interest rate, inflation rate, crude oil price and exchange rate are found to be significant macroeconomic variables towards the gold price. This is evidenced based on the p-values that are less than 5\% significance level. In the term of relationship and impact of the independent variables on the gold price, interest rate poses negative relationship with or negative impact on the gold price. Meanwhile, the other three variables, namely inflation rate, crude oil price and exchange rate pose positive relationship or positive impact on the gold price. The findings imply that when there is a rise in interest rate, then the gold price would drop. This does make sense since when the interest rate increases, then investors will invest more in debt-based investments than gold investment. Another explanation for this finding is that, when interest rate rises, the cost of fund to invest in gold will be more expensive resulting less investors to borrow for the purpose of gold investment. These two scenarios will cause the demand for gold investment to fall that ultimately affects the price of to be affected, namely decline as well.

Meanwhile, the findings for inflation rate indicate that any rise in inflation rate will lead to increase in gold price, and vice versa. This is true as the gold acts as the store of value or hedge instrument or insurance in the event of there is a hike in general prices of goods. For those investors who have gold in their investment portfolio, it is a blessing since they could cover the increase in cost of goods and services by the increase in gold value. Likewise, the impact of rise in crude oil price poses positive impact on the gold price. As both commodities are the two mainly traded commodities in the world market, it is predictable that a rise in one commodity will cause a rise in another commodity. The rise is due to the increase in demand for both commodities specifically by business sectors. The appreciation in currency is also found to have positively affected the gold price. A country's currency appreciation in value reflects the country's economic growth in the world trade. This implies the demand for the country's goods including the commodities such as gold for export has also risen. The factor has directly and positively impacted the gold price.

The result of F-test is 90.57236 while the probability value F-test is 0.0000 . As the p value of F-test is below than 5\%, it indicates and is concluded that all the four independent variables fit this study or do affect the gold price in Malaysia. The value of $R^{2}$ of this study is 0.8681 , which indicates that almost $87 \%$ variation in the gold price is explained by the four independent 
variables. Meanwhile, the remaining of $13 \%$ is determined by other factors not tested in this study. The other results are summarized in Table 5 above.

\section{Conclusion and Recommendation}

This paper attempted to examine the relationship and effect of the macroeconomic variables on the gold price in Malaysia. Based on the monthly time series data from 2014 to 2018, the multiple linear regressions reveal that all the four selected variables, namely interest rate, inflation, crude oil price and exchange rate are significant variables towards the gold price in Malaysia. Out of the four, interest rate is found to have negatively affected the gold price. This current finding is in support of the previous findings by Toraman et al., (2011), Tram (2014), Zakaria et al., (2015) and Laily et al., (2017). Meanwhile, the other three variables pose positive effects on the gold price. The positive finding on the inflation is consistent with San et al., (2012) and Sindhu (2013). However, it is in contrast to Qian et al., (2019) and Ibrahim et al., (2014). The positive effect of crude oil price on the gold price is also consistent with Shafiee and Topal (2010) and Laily et al., (2017) whilst it contradicts the findings by Tram (2014) and Qian et al., (2019). Moreover, this current study evidences positive effect on the gold price by the exchange rate and this finding is in support of the studies by Akar (2011), Tram (2014), Zagaglia and Marzo (2013), and Tsen (2014). Nevertheless, the result is not consistent with Ibrahim et al., (2014) and Zakaria et al., (2015).

Conclusively, we could say that the findings are mixed depending on which countries' macroeconomic variables are tested. This opens for further researches in the future by taking into consideration other macroeconomic variables that could affect the gold price such as the GDP, money supply, industrial production index and other world commodities' prices. Other types of robustness tests could also be employed by future researchers to obtain more enhanced results to support the conclusion. Apparently, the findings are providing useful insight and information to the investors and policy makers in planning, forecasting and decision making particularly related to gold and macroeconomic variables. This study also adds more updates on the current literature to the researchers and academicians of related filed.

\section{References}

Akar, C. (2011). Dynamic Relationships between the Stock Exchange, Gold, and Foreign Exchange Returns in Turkey. Middle Eastern Finance and Economics, 12.

Beckmann, J., \& Czudaj, R. (2013). Gold as An Inflation Hedge in A Time-varying Coefficient Framework. The North American Journal of Economics and Finance, 24, 208-222.

Blose, L. E. (2010). Gold Prices, Cost of Carry, and Expected Inflation. Journal of Economics and Business, 62(1), 35-47.

Hashim, S. L. M., Ramlan, H., Razali, N. H. A., \& Nordin, N. Z. M. (2017). Macroeconomic Variables Affecting the Volatility of Gold Price. Journal of Global Business and Social Entrepreneurship, 3(5), 97-106.

Ibrahim, S. N., Kamaruddin, N. I., \& Hasan, R. (2014). The Determinants of Gold Prices in Malaysia. Journal of Advanced Management Science, 2(1), 38-41.

Jaraskunlanat, N., \& Kijboonchoo, T. (2016). A Study of Factors Affecting the Gold Price in Thailand during 2005-2015. International Research E-Journal, 2(1), 5-18.

Ling, C. (2011). The Relationship Between Gold Price and Exchange Rate of Asean Currencies.

Qian, Y., Ralescu, D. A., \& Zhang, B. (2019). The Analysis of Factors Affecting Global Gold Price. Resources Policy, 64, 1-9. 
San, C. P., Yee, K. P., Keai, P. C., \& Xuan. W. W. (2012). Determinants of Gold Price: Using Simple and Multiple Linear Regression. Research Paper, 3, 1-47.

Shafiee, S., \& Topal, E. (2010). An Overview of Global Gold Market and Gold Price Forecasting. Resources Policy, 35(3), 178-189.

Sindhu, D. (2013). A Study on Impact of Select Factors on the Price of Gold. IOSR Journal of Business and Management, 8(4), 84-93.

Sukri, M. K. A., Mohd Zain, N. H., \& Zainal Abidin, N. S. (2015). The Relationship Between Selected Macroeconomic Factors and Gold Price in Malaysia. Proceeding - Kuala Lumpur International Business, Economics and Law Conference, 8(1), 182-193.

Toraman, C., Başarır, Ç., \& Bayramoğlu, M. F. (2011). Determination of Factors Affecting the Price of Gold: A Study of MGARCH Model. Business and Economics Research Journal, 2(4), 37-50.

Tram, D. N. (2014). The Factors Affecting the Gold Market in Vietnam. (May 2014).

Tsen, W. H. (2014). Exchange Rate and Gold Price: Evidence from Malaysia. Labuan Bulletin of International Business and Finance, 12, 1-18.

Tully, E., \& Lucey, B. M. (2007). A Power GARCH Examination of the Gold Market. Research in International Business and Finance, 21(2), 316-325.

Worthington, A. C., \& Pahlavani, M. (2007). Gold Investment as an Inflationary Hedge: Cointegration Evidence with Allowance for Endogenous Structural Breaks. Applied Financial Economics Letters, 3(4), 259-262.

Zagaglia, P., \& Marzo, M. (2013). Gold and the U.S. Dollar: Tales from the Turmoil. Quantitative Finance, 13(4), 571-582.

Zakaria, H., Abdul Shukur, N., Affandi, S., \& Wan Mahmood, W. (2015). Factors Affecting the Price of Gold in Malaysia. Journal of Basic and Applied Scientific Research, 5(7), 41-46. 